Effects of storage period and temperature upon seed and seedling traits of perennial ryegrass (Lolium perenne 1.)

Utjecaj dužine i temperature skladištenja na svojstva sjemena i klijanaca engleskog ljulja (Lolium perenne L.)

Bukvić, G., Gantner, R., Grljušić, S., Popović, B., Agić, D., Stanisavljević, A.

Poljoprivreda/Agriculture

ISSN: $1848-8080$ (Online)

ISSN: 1330-7142 (Print)

DOI: http://dx.doi.org/10.18047/poljo.21.2.1

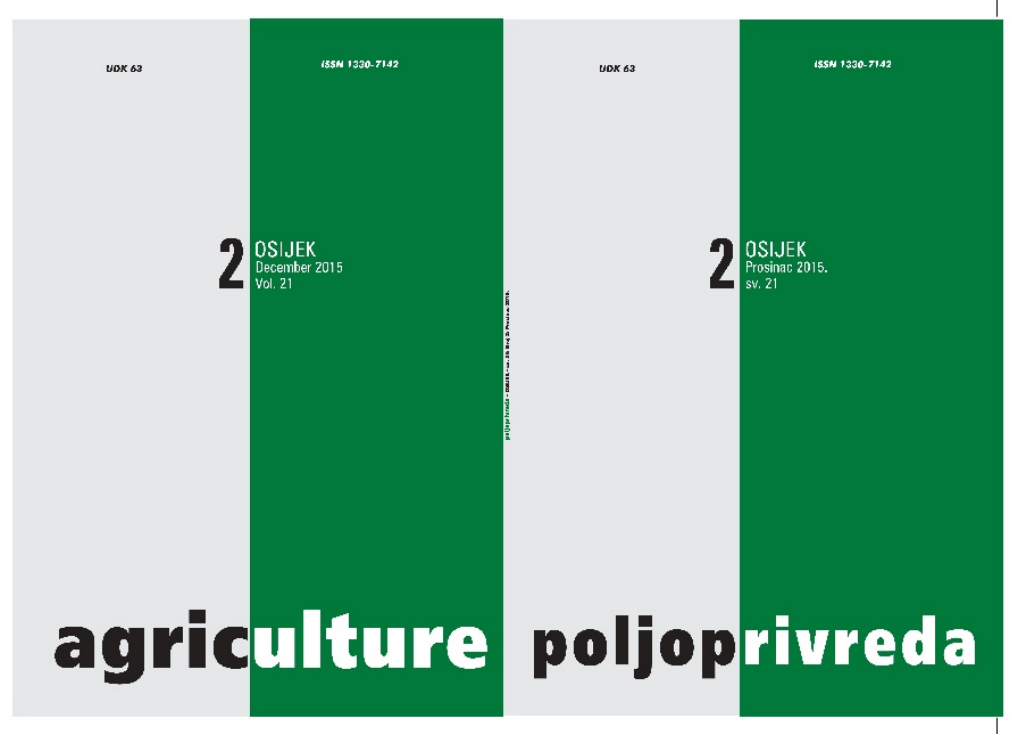

Poljoprivredni fakultet u Osijeku, Poljoprivredni institut Osijek

Faculty of Agriculture in Osijek, Agricultural Institute Osijek 


\title{
EFFECTS OF STORAGE PERIOD AND TEMPERATURE UPON SEED AND SEEDLING TRAITS OF PERENNIAL RYEGRASS (LOLIUM PERENNE L.)
}

Bukvić, G. ${ }^{(1)}$, Gantner, R. ${ }^{(1)}$, Grljušić, S. ${ }^{(2)}$, Popović, B. ${ }^{(1)}$, Agić, D. ${ }^{(1)}$, Stanisavljević, A. ${ }^{(1)}$

Original scientific paper Izvorni znanstveni članak

\begin{abstract}
SUMMARY
$A$ research of seed storage period and storage temperature effects upon the seed quality and seedlings traits for the seeds of two perennial ryegrass cultivars (Bartwingo and Calibra) was conducted. Seeds were stored in hermetically sealed glass dishes at four different temperatures (room temperature about $21^{\circ} \mathrm{C}, 10^{\circ} \mathrm{C},-20^{\circ} \mathrm{C}$ and $-80^{\circ} \mathrm{C}$ ) and for three different periods (9, 18 and 30 months). Upon completing the storage treatments the seed and seedling traits were tested by the rolled filter paper method.

The research has revealed significant effects of storage temperature, storage period, cultivar and interactions upon all the investigated traits. The highest germination energy, germination and seedling plumule length were observed after the shortest (9-month) storage period, and the least after the longest (30-month) storage period. Seedling radicule was longest after 18-month storage period and shortest after 30 months. All the investigated traits had the highest values when seeds were stored at $-80^{\circ} \mathrm{C}$, and the least when the seeds were stored at room temperature. Cultivar Bartwingo has shown a greater germination energy and germination but Calibra has shown a greater seedling radicule and plumule length.
\end{abstract}

Key-words: perennial ryegrass, seed, storage period, temperature

\section{INTRODUCTION}

Field crops' yield and quality are strongly influenced by quality of the seed used. However, seed quality is composed of its genetic, physical, physiological and sanitary traits (Marcos-Filho and McDonald, 1998) which are more or less affected by environmental conditions during the seed's crop vegetation (McDonald, 1998), seed processing (Schaffer and Vanderlip, 1999), seed storage conditions and storing period (Saxena et al., 1987). Among the agroecological conditions, the soil $\mathrm{pH}$ and content of macro- and micro-nutrients have the main impact on seed quality whilst the proper analytical method for a.m. soil traits is crucial for obtaining the data for decision-making process in seed crop's agronomy (Popović et al., 2010).

Storing and seed ageing changes i.e. declines seed's quality (Vieira et al., 2001; Karman et al., 2014). Therefore the seed's vitality and viability may be greatly disturbed during a storing process if it is in inadequate conditions. Critical factors in the storage, according to Elias et al. (2002), are: kind of seed, seed moisture content, initial viability of the seed, storage temperature and relative humidity, storage period and protection from storage fungi and insects.

Optimum storing conditions primarily depend on the species of which the seed is being stored. Generally, the grass seed may be easier to store than maize seed, and maize seed better than soybean (Elias et al., 2002; Šimić et al., 2005). Seeds of small-seed forages may maintain their viability for a very long period in suitable conditions (Griffiths and Pegler, 1964; Lewis et al., 1998). Considering the seed's moisture and storing tem-

(1) Prof. Dr. Gordana Bukvić (gbukvic@pfos.hr), Assist. Prof. Ranko Gantner, Assist. Prof. Brigita Popović, Dejan Agić, Ph.D., Assoc. Prof. Aleksandar Stanisavljević - Josip Juraj Strossmayer University of Osijek, Faculty of Agriculture in Osijek, Kralja Petra Svačića 1d, 31000 Osijek, Croatia, (2) Assist. Prof. Sonja Grljušić - Agricultural Institute Osijek, Južno predgrađe 17, 31000 Osijek, Croatia 
perature, Cattani (2007) reported that perennial ryegrass seed of higher moisture $(20 \%)$ and at higher temperature $\left(25^{\circ} \mathrm{C}\right)$ lost its viability very quickly when compared to lower seed moisture $(10.5 \%)$ and lower storing temperature $\left(5^{\circ} \mathrm{C}\right)$. Ellis and Hong $(2006)$ determined that red clover (Trifolium repens $\mathrm{L}$.) and lucerne (Medicago sativa L.) seed has kept viability over 14.5 years of storage at low moisture (2.2 to $14.9 \%$ for red clover and 2.0 to $12 \%$ for lucerne) and temperature of $-20^{\circ} \mathrm{C}$ when stored at hermetically closed dish. Furthermore, the Bean et al. (1984) research has shown, after 3 to 5 years of storage in aluminium foil at $5 \%$ seed moisture, the higher perennial ryegrass (Lolium perenne L.) seed germination ability when stored at temperatures $-25^{\circ} \mathrm{C}$ and $0^{\circ} \mathrm{C}$ than when stored at $18^{\circ} \mathrm{C}$. Seed of small-seed legumes and grasses may be successfully stored for 12 years in controlled relative air humidity and temperature $\left(2^{\circ} \mathrm{C}\right.$ and relative humidity between 10 and $20 \%$ ) and better than in controlled temperature only $\left(4^{\circ} \mathrm{C}\right)$, Marshall and Lewis (2004).

Ching and Calhoun (1968), and Ching and Schoolcraft (1968) investigated the causes for seeds' viability and vigor decrease in crimson clover (Trifolium incarnatum L.) and perennial ryegrass stored during 10 years at various seed moisture $(6,8,12,16$ i $20 \%)$ and temperature $\left(3,22\right.$ i $\left.38^{\circ} \mathrm{C}\right)$ in a closed can. Upon the results, they concluded that the loss of viability and vigor was not due to depletion of food, but appeared to be related to the activity of proteases, phytase, and phosphatases since an increase of permeability, amino acids, and inorganic phosphate was observed in the aged material. The magnitude of these increases was related to species and seed moisture and to a lesser degree to storage temperature.

Aims of the research were to observe and determine the effects of various seed storage periods and storage temperatures upon seed and seedlings traits of two perennial ryegrass cultivars.

\section{MATERIAL AND METHODS}

The research was conducted using the seeds of two perennial ryegrass cultivars (Table 1).

Table 1. Investigated perennial ryegrass cultivars, country of origin, mass of thousand seeds, seed moisture, and cultivar ploidy

Tablica 1. Podrijetlo, masa 1000 sjemenki, vlaga sjemena i ploidnost kultivara engleskoga ljulja

\begin{tabular}{|l|c|c|c|c|}
\hline $\begin{array}{l}\text { Cultivar } \\
\text { Kultivar }\end{array}$ & $\begin{array}{c}\text { Origin } \\
\text { Podrijetlo }\end{array}$ & $\begin{array}{c}\text { Thousand seed weight (g) } \\
\text { Masa 1000 sjemenki (g) }\end{array}$ & $\begin{array}{c}\text { Seed moisture (\%) } \\
\text { Vlaga sjemena (\%) }\end{array}$ & $\begin{array}{c}\text { Ploidy } \\
\text { Ploidnost }\end{array}$ \\
\hline Bartwingo & Netherlands & 1.92 & 8.4 & Diploid \\
\hline Calibra & Denmark & 3.06 & 10.4 & Tetraploid \\
\hline
\end{tabular}

Prior to the experimental storage initial seed quality parameters (germination energy and germination) and traits of developed seedlings (radicule and plumule length, Table 2) were determined upon conducted germination (ISTA Rules, 2003), as described below.

\section{Table 2. Initial seed and seedling traits}

Tablica 2. Svojstva sjemena i klijanaca kulitvara Bartwingo i Calibra

\begin{tabular}{|l|c|c|c|c|}
\hline $\begin{array}{l}\text { Cultivar } \\
\text { Kultivar }\end{array}$ & $\begin{array}{c}\text { Germination energy (\%) } \\
\text { Energija klijanja (\%) }\end{array}$ & $\begin{array}{c}\text { Germination (\%) } \\
\text { Klijavost (\%) }\end{array}$ & $\begin{array}{c}\text { Radicule length (cm) } \\
\text { Dužina korijena (cm) }\end{array}$ & $\begin{array}{c}\text { Plumule length (cm) } \\
\text { Dužina stabljike (cm) }\end{array}$ \\
\hline Bartwingo & 82.5 & 85.8 & 5.28 & 8.11 \\
\hline Calibra & 68.5 & 68.5 & 6.52 & 9.33 \\
\hline
\end{tabular}

Experimental storage was conducted in hermetically sealed glass dishes, one dish per trial variant. Investigated factors were storage temperature (at four levels: room temperature about $21^{\circ} \mathrm{C}, 10^{\circ} \mathrm{C},-20^{\circ} \mathrm{C}$ and $-80^{\circ} \mathrm{C}$ ) and storage period (at three levels: 9 months, 18 months and 30 months). After completing the experimental storage the seeds were tested for seed quality traits (germination energy and germination) and traits of seedlings (radicule and plumule length) developed after germination. Four replicates of 100 seeds per each trial variant were set out. Seed germination was conducted in a rolled moisturized filter-paper, closed in PVC bags,
The trial was set up in a split-plot design type in four replicates. The main effect was storage period (S), while the split-effects were temperature of storage (T) and cultivars (C). 


\section{RESULTS AND DISCUSSION}

All the investigated seed and seedling traits of perennial ryegrass were significantly affected by storage period, temperature and genotype (Table 3). Also, significant interactions were detected among treatments.

Average values of germination energy varied with cultivar, storage period and temperature of storage in the range from 2.5 to $84 \%$ (Figure 1). Considering the storage period, the highest values for germination energy, when averaged over cultivars and temperatures, were obtained for the shortest storing period and prolonged storing has significantly $(p<0.01)$ lowered the germination energy (Table 4). Also germination energy has been significantly $(p<0.01)$ decreased with the increase of storing temperature, when averaged over cultivars and storing periods. The results were in harmony with findings of Rozman et al. (2010) who inve- stigated the same cultivars for storing at $10^{\circ} \mathrm{C},-20^{\circ} \mathrm{C}$ and $-80^{\circ} \mathrm{C}$ for period of 9 moths. The Bartwingo cultivar had significantly $(p<0.01)$ higher germination energy than Calibra, exceeding it BY $13 \%$ when averaged over storing periods and temperatures. When compared to the initial germination energy (Table 1), the experiment has decreased the germination energy BY $10 \%$ for Bartwingo and 9\% for Calibra on the average. The finding was in accordance with the Palada (2010) report who found out the $38 \%$ germination energy fall in perennial ryegrass upon 3 -year storing period, both in controlled environment $\left(10^{\circ} \mathrm{C}\right.$ and $50 \%$ relative air humidity) and uncontrolled one in the 3-year research. Palada (2010) observed that diploid cultivars dropped the germination energy more severely (by about $50 \%$ ) than tetraploid ones (by about 25\%).

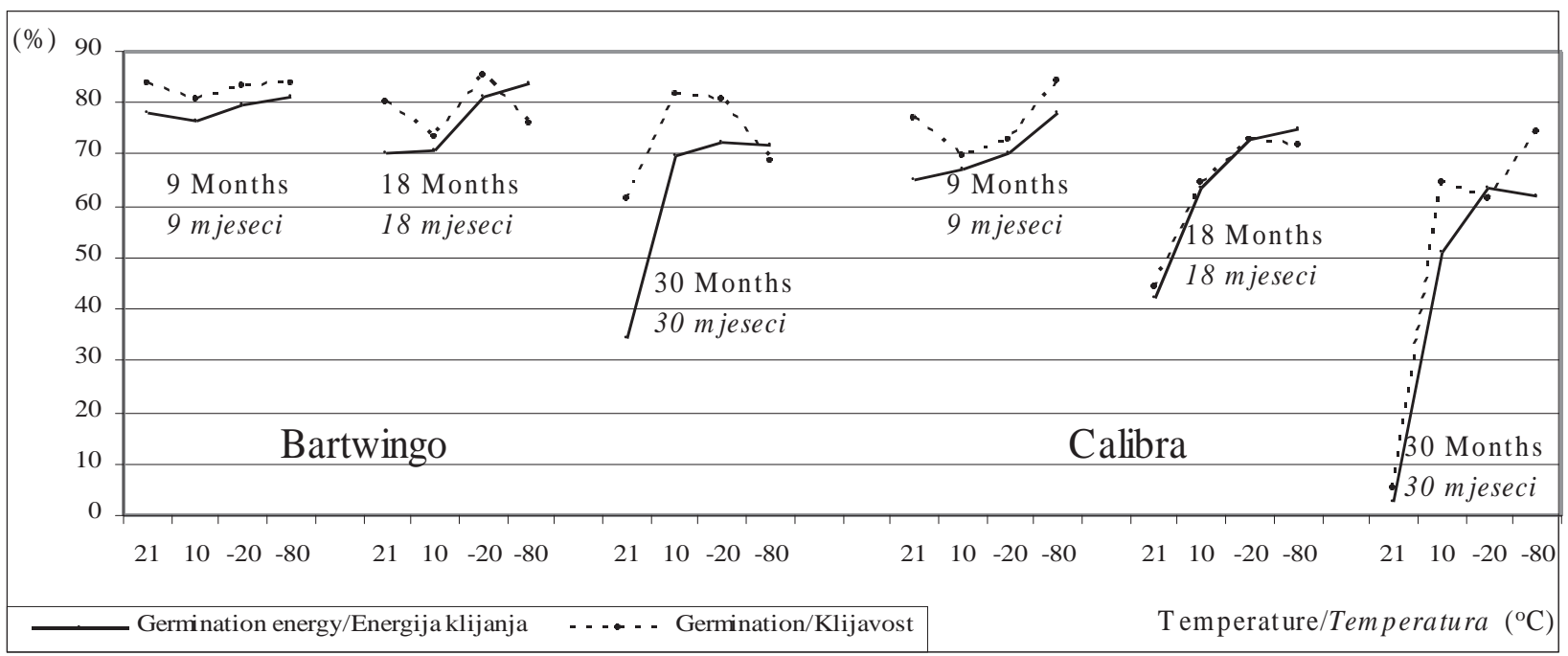

Figure 1. Germination energy and germination (\%) of perennial ryegrass seed at varying storage period and storage temperature

Grafikon 1. Energija klijanja i klijavost (\%) sjemena kultivara engleskoga ljulja pri različitoj dužini i temperaturi skladištenja

Average values of germination varied with cultivar, storage period and storage temperature in the range from 5.1 to $85 \%$ (Figure 1). Germination, when averaged over cultivars and storing temperatures, has been significantly $(p<0.01)$ decreased with the increase of storing period. The finding was in line with Palada's (2010) results. Stanisavljević et al. (2011) have also observed the significant decrease (69\%) of germination perennial ryegrass after storage. They reported the maximum germeability (93\%) after 270 -day storage period, the medium after 540-day storage period and the lowest after 990-day storage period, with the final fall of $69 \%$ when compared to the initial germeability. Germination has been decreased significantly $(p<0.01)$ with the increase of storage temperature when averaged over cultivars and storing periods (Table 4) being in accordance with Rozman et al. (2010) who found the highest germination when seeds were stored at $-80^{\circ} \mathrm{C}$ after 9 -month storage period. The result was in conformity with Ackigoz and Knowles (1983) who investigated the seeds of three grass species stored at five different temperature levels $\left(21,5,1,-7\right.$ and $\left.-18^{\circ} \mathrm{C}\right)$ during 12 years in various sorts of packages. The germination was maintained highest at $-18^{\circ} \mathrm{C}$ and somewhat lower when seeds were stored at $-7^{\circ} \mathrm{C}$, but it was lost when seeds were stored at above zero temperatures, regardless to sort of package.

Hampton and Bell (1989) investigated the effects of seed moisture $(9.7,11.9$ and $14.9 \%)$ and storing period $(1,3,6,12$ and 18 months) upon germination of prairie grass (Bromus willdenowii Kunth) seeds. They found the greatest fall of germination at the highest seed moisture and storing period of 12 months at $10^{\circ} \mathrm{C}$.

In the present research the Bartwingo cultivar has shown $14.6 \%$ higher average germination $(p<0.01)$ than Calibra. When compared to the initial values (Table 1), diploid cultivar Bartwingo has shown the greater 
average fall of germination (7.6\%) than tetraploid Calibra (5\%). Similarly, the Palada's (2010) research has revealed greater loss of germination in diploid cultivars than in tetraploid ones despite the greater initial germination at diploid ones.

Average radicules' length ( $R L$ in further) varied from 1.36 to $7.22 \mathrm{~cm}$ (Figure 2), depending on the research treatment. Average RL varied significantly $(p<0.01)$ with storing period. Storing period effects to $R L$ were not consistent with the effects to germination energy and germination. The highest RL was observed upon 18 months storage period, medium after 9 months of storage and lowest after 30 months (Table 4). Stanisavljević et al. (2011.) found the highest values $(7 \mathrm{~cm})$ of perennial ryegrass hypocotil length after 350-days long seed storing period whilst the final length (after 990 days) was $6.6 \mathrm{~cm}$.

The storing temperature also significantly $(p<0.01)$ affected the $\mathrm{RL}$. The highest $\mathrm{RL}$ was observed upon storage at $-80^{\circ} \mathrm{C}$ (Table 4 ) and the least upon room temperature $\left(21^{\circ} \mathrm{C}\right)$.

Cultivar Calibra has shown the greater $(p<0.01)$ average $\mathrm{RL}$ than Bartwingo, for $1.06 \mathrm{~cm}$ (or 28\%), being opposite to the exhibited germination energy and germination performance. The storage experiment has decreased RL when compared to the initial one (Table 1), for $0.38 \mathrm{~cm}$ for Bartwingo and for $0.56 \mathrm{~cm}$ for Calibra.

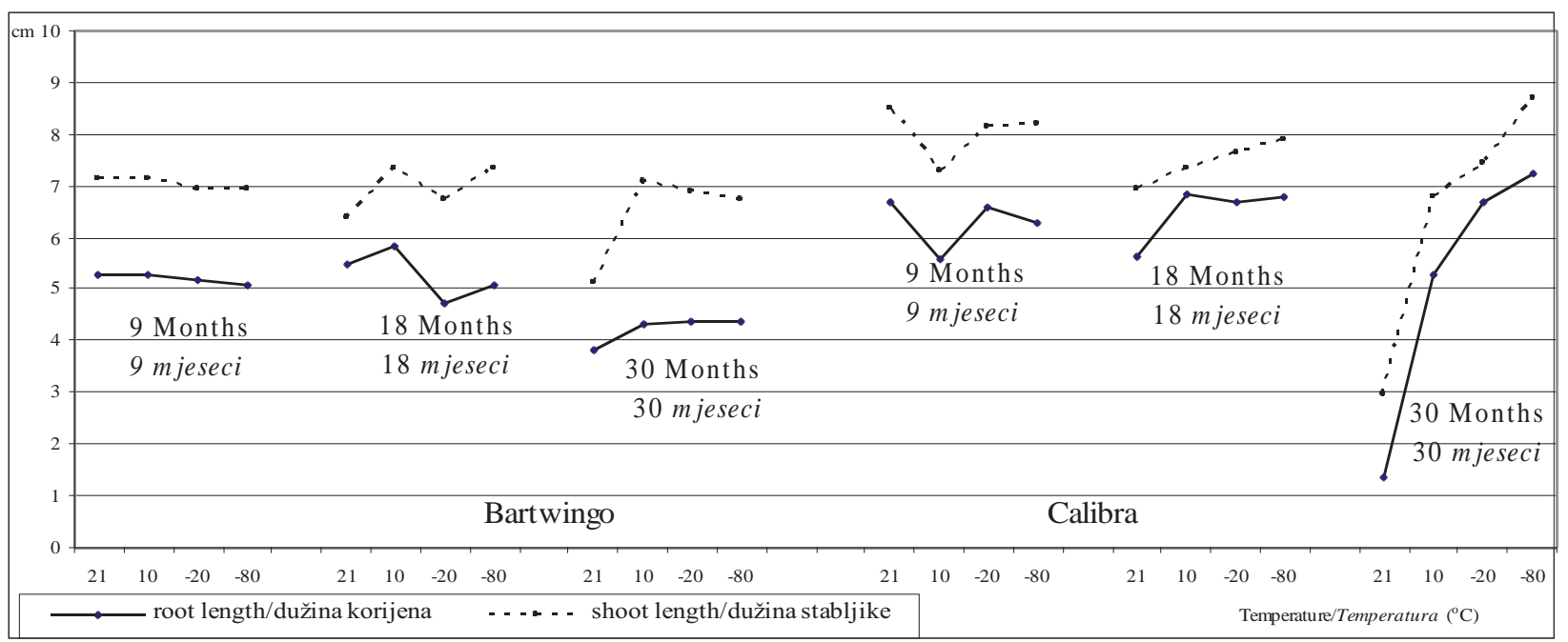

Figure 2. Seedlings plumule and radicule length $(\mathrm{cm})$ of perennial ryegrass cultivar at varying storage period and storage temperature

Grafikon 2. Dužina stabljike i korijena klijanaca (cm) kultivara engleskoga ljulja pri različitoj dužini i temperaturi skladištenja

Table 3. LSD values for the investigated traits of perennial ryegrass at different storage periods and temperatures Tablica 3. Prikaz LSD vrijednosti za ispitivana svojstva sorata engleskog ljulja pri različitoj dužini i temperaturama skladištenja

\begin{tabular}{|c|c|c|c|c|c|c|c|}
\hline LSD & $S$ & $\mathrm{~T}$ & $\mathrm{C}$ & $S \times T$ & $\mathrm{~S} \times \mathrm{C}$ & $\mathrm{T} \times \mathrm{C}$ & $S \times T \times C$ \\
\hline \multicolumn{8}{|c|}{ Germination energy / Energija klijanja } \\
\hline 0.05 & 0.2339 & 0.2700 & 0.1909 & 0.4677 & 0.3307 & 0.3819 & 0.6614 \\
\hline 0.01 & 0.3110 & 0.3591 & 0.2540 & 0.6221 & 0.4399 & 0.5079 & 0.8797 \\
\hline \multicolumn{8}{|c|}{ Germination / Klijavost } \\
\hline 0.05 & 0.2841 & 0.3281 & 0.2320 & 0.5683 & 0.4018 & 0.4640 & 0.8036 \\
\hline 0.01 & 0.3779 & 0.4364 & 0.3085 & 0.7558 & 0.5344 & 0.6171 & 1.0688 \\
\hline \multicolumn{8}{|c|}{ Radicule length / Dužina korijena klijanaca } \\
\hline 0.05 & 0.0443 & 0.0512 & 0.0362 & 0.0887 & 0.0627 & 0.0724 & 0.1254 \\
\hline 0.01 & 0.0590 & 0.0681 & 0.0482 & 0.1180 & 0.0834 & 0.0963 & 0.1668 \\
\hline \multicolumn{8}{|c|}{ Plumule length / Dužina stabljike klijanaca } \\
\hline 0.05 & 0.0388 & 0.0448 & 0.0317 & 0.0776 & 0.0549 & 0.0634 & 0.1097 \\
\hline 0.01 & 0.0516 & 0.0596 & 0.0421 & 0.1032 & 0.0730 & 0.0843 & 0.1460 \\
\hline
\end{tabular}


Average plumules' length (PL in further) varied from 2.95 to $8.71 \mathrm{~cm}$ (Figure 2). Storing period significantly $(p<0.01)$ shortened SL (Table 4). The observation was in line with the findings of Stanisavljević et al. (2011) who found the greater PL in perennial ryegrass $(8.4 \mathrm{~cm})$ upon 200 to 650 days storing period than upon 990 days $(8 \mathrm{~cm})$ storage period.

PL was significantly $(p<0.01)$ affected by storing temperature too. The highest PL was observed for storing at $-80^{\circ} \mathrm{C}$ (Table 4 ) and the lowest at $21^{\circ} \mathrm{C}$.

Opposite to the lower germination energy and germination for the tetraploid Calibra, generally greater $(p<0.01)$ PL in Calibra than in diploid Bartwingo, for $0.51 \mathrm{~cm}$ or $7 \%$ was observed, being in conformity with findings of Rozman et al. (2010). Smith et al. (2003), in their research of ploidy level and seed mass effects upon the early vigor of perennial ryegrass, found, at 33-days old plantlets, the lesser shoots and greater above-ground herbage at tetraploid than in diploid cultivars. They explained this phenomenon as a consequence of "Gigas" effect, i.e. the greater cell of polyploids. When compared to the initial values (Table 1), the experiment has decreased SL for $1.3 \mathrm{~cm}$ on the average for Bartwingo and for $2.01 \mathrm{~cm}$ for Calibra.

Table 4. The effects of seed storing temperature and storing period on seed and seedlings traits of investigated perennial ryegrass cultivars

Tablica 4. Utjecaj temperature i vremena skladištenja na svojstva sjemena i klijanaca ispitivanih kultivara engleskoga ljulja

\begin{tabular}{|c|c|c|c|c|}
\hline \multirow{2}{*}{\begin{tabular}{|l} 
Storage \\
temperature $(\mathrm{T})$ \\
Temperatura skladištenja $(T)$
\end{tabular}} & \multicolumn{3}{|c|}{$\begin{array}{c}\text { Storing period (months) (S) } \\
\text { Dužina skladištenja (mjeseci)(S) }\end{array}$} & \multirow[t]{2}{*}{$\begin{array}{l}\text { Average }(\mathrm{SxT}) \\
\text { Prosjek }(\mathrm{S} x \mathrm{~T})\end{array}$} \\
\hline & 9 & 18 & 30 & \\
\hline & \multicolumn{4}{|c|}{ Germination energy (\%) / Energija klijanja (\%) } \\
\hline $\mathrm{RT}^{*}$ & 71.75 & 56.13 & 18.50 & $48.79^{d}$ \\
\hline $10^{\circ} \mathrm{C}$ & 71.75 & 67.00 & 60.25 & $66.33^{\mathrm{c}}$ \\
\hline$-20^{\circ} \mathrm{C}$ & 74.88 & 76.88 & 67.88 & $73.21^{\mathrm{b}}$ \\
\hline$-80^{\circ} \mathrm{C}$ & 79.63 & 79.50 & 66.75 & $75.29^{a}$ \\
\hline \multirow[t]{2}{*}{ Average/Prosjek } & $74.50^{\mathrm{a}}$ & $69.88^{\mathrm{b}}$ & $53.35^{c}$ & 65.91 \\
\hline & \multicolumn{4}{|c|}{ Germination (\%) / Klijavost (\%) } \\
\hline $\mathrm{RT}^{*}$ & 80.38 & 62.25 & 33.25 & $58.63^{c}$ \\
\hline $10^{\circ} \mathrm{C}$ & 75.25 & 69.00 & 73.13 & $72.46^{\mathrm{b}}$ \\
\hline$-20^{\circ} \mathrm{C}$ & 77.88 & 79.13 & 71.00 & $76.00^{\mathrm{a}}$ \\
\hline$-80^{\circ} \mathrm{C}$ & 83.88 & 73.88 & 71.50 & $76.42^{\mathrm{a}}$ \\
\hline \multirow[t]{2}{*}{ Average/Prosjek } & $79.35^{\mathrm{a}}$ & $71.07^{\mathrm{b}}$ & $62.22^{\mathrm{c}}$ & 70.88 \\
\hline & \multicolumn{4}{|c|}{ Radicule length $(\mathrm{cm}) /$ Dužina korijena klijanaca $(\mathrm{cm})$} \\
\hline $\mathrm{RT}^{*}$ & 5.96 & 5.54 & 2.59 & $4.70^{\mathrm{d}}$ \\
\hline $10^{\circ} \mathrm{C}$ & 5.44 & 6.33 & 4.79 & $5.52^{c}$ \\
\hline$-20^{\circ} \mathrm{C}$ & 5.87 & 5.70 & 5.53 & $5.70^{\mathrm{b}}$ \\
\hline$-80^{\circ} \mathrm{C}$ & 5.67 & 5.91 & 5.80 & $5.79^{\mathrm{a}}$ \\
\hline \multirow[t]{2}{*}{ Average/Prosjek } & $5.74^{\mathrm{b}}$ & $5.87^{a}$ & $4.68^{c}$ & 5.43 \\
\hline & \multicolumn{4}{|c|}{ Plumule length (cm) / Dužina stabljike klijanaca (\%) } \\
\hline $\mathrm{RT}^{*}$ & 7.81 & 6.66 & 4.03 & $6.17^{d}$ \\
\hline $10^{\circ} \mathrm{C}$ & 7.21 & 7.35 & 6.92 & $7.16^{\mathrm{c}}$ \\
\hline$-20^{\circ} \mathrm{C}$ & 7.52 & 7.18 & 7.17 & $7.29^{b}$ \\
\hline$-80^{\circ} \mathrm{C}$ & 7.56 & 7.64 & 7.71 & $7.64^{\mathrm{a}}$ \\
\hline Average/Prosjek & $7.53^{\mathrm{a}}$ & $7.21^{\mathrm{b}}$ & $6.46^{c}$ & 7.06 \\
\hline
\end{tabular}

*room temperature $\left( \pm 21^{\circ} \mathrm{C}\right)$

\section{CONCLUSION}

According to the research results of storage temperature effects of two perennial ryegrass cultivars upon seed and seedling traits determined after 9, 18 and 30 months storage periods, the following conclusions can be drawn:

- Seed and seedling traits varied significantly under effects of storage period, temperature, cultivar and interactions between the effects.

- Values of germination energy, germeability and length of plumule were decreasing with increa- ses of storage period whilst the radicule length was highest after 18 month of storage.

- All the enquired traits had maximum values when seeds were stored at $-80^{\circ} \mathrm{C}$ and the lowest at room temperature.

- Bartwingo cultivar, on the average, had greater germination energy and germeability whereas Calibra had greater radicule and plumule length.

Seed quality loss storage is an unavoidable process. In order to preserve the seed quality, especially during longer storing period the optimum storage con- 
ditions (temperature of storage, seed's moisture) which primarily depend on the plant species, variety and ploidy level should be chosen.

\section{REFERENCES}

1. Ackigoz, E., Knowles, R.P. (1983): Long-term storage of grass seeds. Can. J. Plant Sci., 63: 669-674. doi: http://pubs.aic.ca/doi/abs/10.4141/cjps83-084

2. Bean, E.W., Sengul, S., Tyler, B.F. (1984): The germination of grass seeds after storage at different temperatures in aluminium foil and manilla paper packets. Annals of Applied Biology, 105(2): 399-403.

doi: http://dx.doi.org/10.1111/j.1744-7348.1984.tb03065.x

3. Cattani, D. (2007): Perennial Ryegrass Seed Production. $8^{\text {th }}$ Annual Mantioba Agronomists Conference, 11-22 December 2007.

http://www.umanitoba.ca/faculties/afs/MAC proceedings/proceedings/2007/Doug_Cattani.pdf

4. Ching, T.M., Calhoun, W. (1968): Productivity of 10-YearOld Canned Forage Seeds. Agronomy Journal, 60(4): 393-394.

doi: http://dx.doi.org/10.2134/agronj1968.00021962006 $000040018 x$

5. Ching, T.M., Schoolcraft, I. (1968): Physiological and chemical differences in aged seeds. Crop Science, 8(4): 407-409.

doi: http://dx.doi.org/10.2135/cropsci1968.0011183X0 00800040003x

6. Elias, S., Garay, A., Young, B., Chastain, T. (2002): Maintaining seed viability in storage: A brief review of management principles with emphasis on grass seeds stored in Oregon. Technical Brochures. Seed Laboratory at Oregon State University.

http://seedlab.oregonstate.edu/maintaining-grass-seed-viability-storage

7. Ellis, R.H., Hong, T.D. (2006): Temperature sensitivity of the low-moisture-content limit to negative seed longevity-moisture content relationships in hermetic storage. Annals of Botany 97(5):785-791.

doi: http://dx.doi.org/10.1093/aob/mcl035

8. Griffiths, D.J., Pegler, R.A.D. (1964): The effects of longterm storage on the viability of S23 perennial ryegrass seed and on subsequent plant development. Grass and Forage Science, 19(2): 183-190. doi: http://dx.doi.org/10.1111/j.1365-2494.1964.tb01160.x

9. Hampton, J.G., Bell, D.D. (1989): Seed quality and storage performance of prairie grass (Bromus willdenowii Kunth) cv. Grasslands Matua. New Zealand Journal of Agricultutral Research 32:139-143. doi: http://dx.doi.org/10.1080/00288233.1989.10423447

10. ISTA Rules (2003): International Association for Seed Testing.

11. Karaman, S., Toker, Ö.S., Öztürk, İ., Yalçin, H., Kayacier, A., Doğan, Sağdiç, 0. (2014): A response surface methodology study on the effects of some phenolics and storage period length on vegetable oil quality: change in oxidation stability parameters. Turk. J. Agric. For., 38(6): 759-772.

doi: http://dx.doi.org/10.3906/tar-1403-98

12. Lewis, D.N., Marshall, A.H., Hides, D.H. (1998): Influence of storage conditions on seed germination and vigour of temperate forage species. Seed Science and Technology, 26(3): 643-655.

13. Marcos-Filho, J., McDonald, M.B. (1998): Sensitivity of RAPD analysis. Germination and vigour tests to detect the intensity of deterioration of naturally and artificially aged soybean seeds. Seed Science and Technology, 26: 141-157.

14. Marshall, A.H., Lewis, D.N. (2004): Influence of seed storage conditions on seedling emergence, seedling growth and dry matter production of temperate forage grasses. Seed Science and Technology, 32(2): 493-501. doi: http://dx.doi.org/10.15258/sst.2004.32.2.19

15. McDonald, M.B. (1998): Seed quality. Seed Science Research, 8: 265-275. doi: http://dx.doi.org/10.1017/S0960258500004165

16. Palada, F. (2010): Diploid and tetraploid varieties of the Lolium perenne behavior under the influence of storage years and storage conditions. Scientific Papers. UASVM Bucharest. Series A. Vol. LIII: 465-471.

17. Popović, B., Šeput, M., Lončarić, Z., Andrišić, M., Rašić, D., Karalić, K. (2010): Comparison of AL P and Olsen $\mathrm{P}$ test in calcareous soils in Croatia. Poljoprivreda/ Agriculture/, 16(1): 38-42.

18. Rozman, V., Bukvić, G., Liška, A., Baličević, R., Eđed, A., Petrović, S. (2010): Differences in traits od seeds and seedlings of perennial ryegrass cultivars after nine months storage at different temperatures. Not. Bot. Hor. Agrobot., 38(1): 155-158.

19. Saxena, O.P., Singh, G., Pakeeraiah, T., Pandey, N. (1987): Seed deterioration studies in some vegetable seeds. Acta Horticulturae, 215: 39-44. doi: http://dx.doi.org/10.17660/ActaHortic.1987.215.5

20. Schaffer, A.F., Vanderlip, R.L. (1999): The effect of conditioning on soybean seed quality. Journal of Production Agriculture, 12: 455-459. doi: http://dx.doi.org/10.2134/jpa1999.0455

21. Smith, K.F., McFarlane, N.M., Croft, V.M., Trigg, P.J., Kearney, G.A. (2003): The effects of ploidy and seed mass on the emergence and earley vigour of perennial ryegrass (Lolium perenne L.) cultivars. Australian Journal of Experimental Agriculture, 43: 48-486. doi: http://dx.doi.org/10.1071/EA01130

22. Stanisavljevic, R., Djokic, D., Milenkovic, J., Đukanovic, L., Stevovic, V., Simic, A., Dodig, D. (2011): Seed germination and seedling vigour of Italian ryegrass, cocksfoot and timothy following harvest and storage. Ciência e Agrotenologia, 35(6): 1141-1148. doi:http://dx.doi.org/10.1590/S1413-70542011000600014

23. Šimić, B., Vratarić, M., Sudarić, A., Krizmanić, M., Andrić, L. (2005): Effect of storage longevity under different storage conditions on seed vigor and oil content in maize, soybean and sulfoner. Poljoprivreda/Agriculture/, 11(2): 12-17.

24. Vieira, R.D., TeKrony, D.M., Egeli, D.B., Rucker, M. (2001): Electrical conductivity of soybean seeds after storage in several environments. Seed Sci. Technol., 29(3): 599-608. 


\section{UTJECAJ DUŽINE I TEMPERATURE SKLADIŠTENJA NA SVOJSTVA SJEMENA I KLIJANACA ENGLESKOG LJULJA (Lolium perenne L.)}

\section{SAŽETAK}

Istraživanje utjecaja dužine i temperature skladištenja na svojstva sjemena i klijanaca engleskoga ljulja provedeno je sa sjemenom dva kultivara (Bartwingo i Calibra). Sjeme je pohranjeno u hermetički zatvorene staklene posude na sobnoj temperaturi te na 10, -20 i $-80^{\circ} \mathrm{C}$. Navedena svojstva mjerena su nakon 9,18 i 30 mjeseci skladištenja metodom rolanoga filter papira. Dobiven je značajan utjecaj temperature, dužine skladištenja $i$ kultivara te njihove interakcije za sva isptivana svojstva. Najveće vrijednosti za energiju klijanja i klijavost sjemena te dužinu stabljike dobivene su nakon 9 mjeseci skladištenja, a najmanje nakon 30 mjeseci. Korijen klijanaca bio je najduži nakon 18, a najkraći nakon 30 mjeseci skladištenja. Sva ispitivana svojstva imala su najveće vrijednosti skladištenjem na $-80^{\circ} \mathrm{C}$, a najmanje na sobnoj temperaturi. Kultivar Bartwingo imao je veću energiju klijanja i klijavost, a Calibra dužinu korijena i klijanaca.

Ključne riječi: engleski ljulj, sjeme, dužina skladištenja, temperatura

(Received on 13 March 2015; accepted on 13 October 2015 - Primljeno 13. ožujka 2015.; prihvaćeno 13. listopada 2015.) 